\title{
Encountering Covid-19 in the Stock Market Context
}

\section{Nurfahiratul Azlina Binti Ahmad, Hainnuraqma Binti Rahim}

To Link this Article: http://dx.doi.org/10.6007/IJARBSS/v11-i11/11592

DOI:10.6007/IJARBSS/v11-i11/11592

Received: 21 September 2021, Revised: 23 October 2021, Accepted: 04 October 2021

Published Online: 15 November 2021

In-Text Citation: (Ahmad \& Rahim, 2021)

To Cite this Article: Ahmad, N. A. B., \& Rahim, H. B. (2021). Encountering Covid-19 in the Stock Market Context. International Journal of Academic Research in Business and Social Sciences, 11(11), 1025 - 1032.

\section{Copyright: (c) 2021 The Author(s)}

Published by Human Resource Management Academic Research Society (www.hrmars.com)

This article is published under the Creative Commons Attribution (CC BY 4.0) license. Anyone may reproduce, distribute, translate and create derivative works of this article (for both commercial and non-commercial purposes), subject to full attribution to the original publication and authors. The full terms of this license may be seen at: http://creativecommons.org/licences/by/4.0/legalcode

Vol. 11, No. 11, 2021, Pg. $1025-1032$

Full Terms \& Conditions of access and use can be found at http://hrmars.com/index.php/pages/detail/publication-ethics 


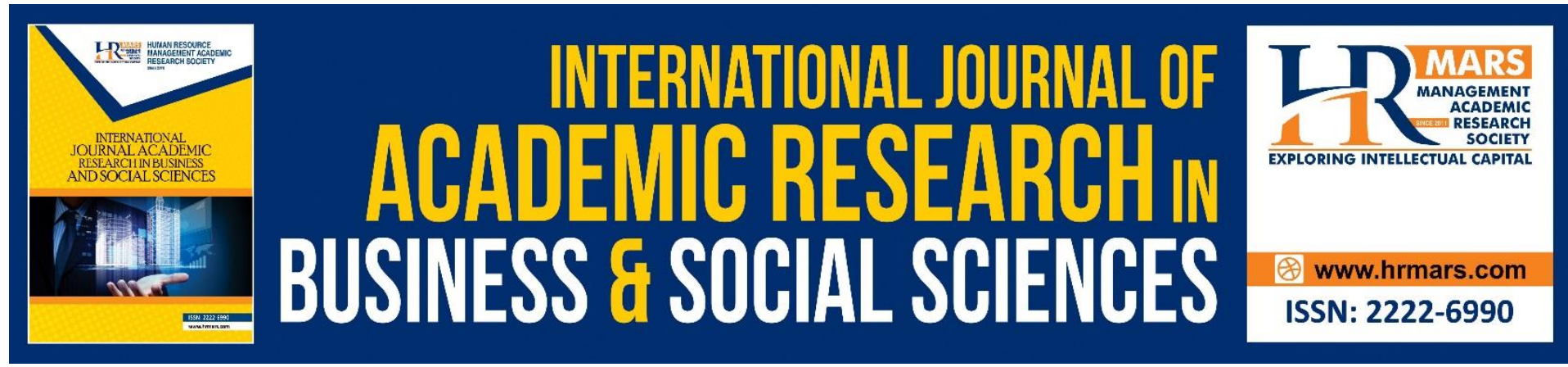

\title{
Encountering Covid-19 in the Stock Market Context
}

\author{
${ }^{1}$ Nurfahiratul Azlina Binti Ahmad, ${ }^{2}$ Dr Hainnuraqma Binti Rahim \\ ${ }^{1}$ Academy of Contemporary Islamic Studies (ACIS), Universiti Teknologi MARA, Cawangan \\ Pulau Pinang, Kampus Permatang Pauh, 13500 Pulau Pinang, Malaysia, ${ }^{2}$ Faculty of Business \\ Management, Universiti Teknologi MARA, Cawangan Melaka, Kampus Alor Gajah, 78000 \\ Melaka, Malaysia \\ Email: hainnuraqma@uitm.edu.my,fahiratul@uitm.edu.my
}

\begin{abstract}
COVID-19 has hit the world tremendously and transformed regular daily routines into a new normative way of life. The consequence of COVID-19 has had a notable impression on the world economy, including current world investment. Therefore, investors nowadays have to face changes in their investments. The hurdles of the overall world economy are making the stock market decline day by day. Accordingly, investors should be wise to ascertain the appropriate time to enter the market to invest than before. Hence, this research attempted to explain the current market situation with the situation of investors. This study was administered based on a literature review that highlighted the writings and results of prior studies related to the stock market in Malaysia. Generally, the method used to produce this study was a qualitative approach that included highlighting and analysing secondary data obtained through documents, research results, or reviewed writings. The data captured were then analysed systematically using content analysis techniques writing. This survey was done, and the results confirmed that even though investors were worried, anxious and desired it all to end soon, they still strived their best to deliver and invest as best they could by gaining knowledge in whatever method they could to ensure they were not failing continuously in this volatile market as the impacts of the COVID-19 pandemic.
\end{abstract}

Keywords: COVID-19, Investment, Economy

\section{Introduction}

The ongoing COVID-19 pandemic is now presenting its contradictory impact on the local and global economy. It is indisputable by the world now because what has transpired has affected all sectors, one of which is the stock market. The stock market is one of the crucial sources of financing to grow a business (Bayraktar, 2014). Companies can increase their funding sources by selling their company ownership on the capital market. The funds raised are for long-term applications to optimise and upgrade the performance of their businesses (Bose et al., 2019). The company then endeavours to secure and grow investor confidence by providing its best accomplishment in the market, including the Islamic stock market (Abdulkarim et al., 2020). 
Stock market developments lead to concrete contributions to economic growth in the country (Aali-Bujari et al., 2017).

An efficient stock market experiences good economic growth and simulates a positive relationship, both short and long term. It demonstrates that the transmission mechanism affects expansion and stock market investment (Coşkun et al., 2017; Lawal et al., 2018). Investors favour investing in countries with low unemployment rates, low social inequality and income gaps, low crime rates, and relatively stable politics and security conditions. Thus, the more stable the economic and political situation of the country, the better and more steady the stock market will be. The COVID-19 pandemic that immediately spread around the world initially did not affect the stock market. Nevertheless, with the rapid rise in mortality, the market began to respond negatively (Ashraf, 2020; Khan et al., 2020; Lyócsa et al., 2020). The COVID-19 also triggered stock market price declines, essentially following the World Health Organization (WHO) publishing its pandemic status, prompting negative abnormal returns in the stock market (Alali, 2020; Liu et al., 2020).

\section{Research Methodology}

The method of this research included two stages, particularly the process of data collection and data analysis. Data collection methods referred to qualitative studies that were taken from literature review and secondary data analysis. As the COVID-19 pandemic subject is comparatively fresh in Malaysia, this literature review relied profoundly on online sources such as news, guides issued by the ministry of health, book sources, articles and appropriate written materials, particularly those linked to stock performance developments and pandemic COVID-19.

\section{Data Analysis Methods}

During this stage, the researchers employed inductive and deductive methods. This method concentrates on the specific data to produce a general conclusion on a problem that applies (Inayah, 1990). Based on this inductive method, an analysis could conclude that the same impact will result if the same factors transpire. On the other hand, the deductive method enabled the researchers to determine that what happens during this pandemic is parallel or vice versa.

\section{Stock Market Effects During the Covid-19 Pandemic}

The essential purpose of this study was to examine how the COVID-19 epidemic affected all sectors in the Malaysian stock market. In addition, this study strived to examine the effects of financial market volatility on the Malaysian stock market. This study's results could benefit investors to recognise the impact of COVID-19 on the performance of various sectors in Malaysia.

Bursa Malaysia performance dwindled during the early MCO as investors sold securities out of concern for the expected economic impact caused by the virus (Aruna, 2020). The majority of COVID-19 research is currently more focused on specific countries (Ramelli \& Wagner, 2020; 2020; Al-Awadhi et al., 2020) except for research by Ashraf (2020), which adopted new confirmed cases and deaths daily from 64 countries. This research reported that that the stock market reacted negatively to the growth of new confirmed cases. His study determined that the stock market was more reactive to new confirmed cases rather than an 
increase in the number of deaths. In general, adverse market reactions were more substantial in the early stages of the outbreak, while the stock market reacted promptly to COVID-19 news depending on the extent of the outbreak.

Ashraf's (2020) data was in line with Erdem's (2020), in which the COVID-19 outbreak had a significant adverse effect on the stock market. They indicated that the growth in the number of new cases on stock returns was about three times more than the growth in the number of deaths. Using the Freedom Index as an independent variable, investors revealed that the impact on stock market returns in independent countries was lower than that in less independent countries for each increase in cases per million. In addition, Lei and Wisniewski (2018) recognised that foreclosures are more likely to occur in autocratic countries (rather than democratic or independent countries) in the midst of economic challenges. There is a possibility of prolonged mismanagement of the company that could lower the firm's value in periods of uncertainty. Malaysia is a "flawed democracy" nation, relatively inferior in democratic practices and complete independence as assessed by the Economic Intelligence Unit's Democracy Index (The Economist, 2020). With a freedom index record of 52/100 (Freedom House, 2020), Malaysia is deemed partially independent or relatively low to moderate in measuring political rights and civil liberties.

\section{Measures Taken}

The Stock Market Stimulus and Performance Package has been executed to curb the consequences of the COVID-19 pandemic by the Malaysian government by originating a stimulus package worth RM295 billion. The RM250 billion Caring "caring package" or economic stimulus package (Povera, 2020) was declared on March 27, 2020, followed by a drastic six-month loan moratorium offered by Bank Negara Malaysia (BNM) to lessen the financial impact of the movement control order. Of that amount, RM128 billion was channelled into guarding the well-being of the people, and RM100 billion was imparted to support businesses, including small and medium enterprises (SMEs). On April 6, a unique stimulus plan worth RM10 billion was announced to assist small and medium enterprises (SMEs) in mitigating the impact of MCOs (Daim, 2020). An extra Short-Term Economic Recovery Plan (Penjana) with 40 initiatives worth RM35 billion was also declared on June 5 2020, to mitigate the epidemic's impact (Loheswar, 2020). The Malaysian government also took various agencies, such as banning short selling from reducing the capital market challenges caused by MCOs. The public received the announcement positively, and the positive feedback in the stock market was evident (Zainul, 2020).

Other economic circumstances also influence stock market reactions as globalisation has motivated economies worldwide to be more interdependent. It grew synchronisation in the global stock market and was mainly influenced by stock market movements in the United States. Consistent with the efficient market hypothesis (EMH), it suggests that investors will be more optimistic when they perceive the news positively impacting the market. On the other hand, if investors consider the news bad, then sentiment becomes somewhat pessimistic, and the market will show a downward bent.

Based on this hypothesis, stock prices reflect all available information, and stocks are always traded at their fair value on the stock exchange. On the other hand, according to the semi-strong $\mathrm{EMH}$, it argued that security pricing has taken into account publicly available 
market information but not material non-public information. Superior gain is likely if there is non-public material information.

The pandemic struck the capital market, causing changes in trading many times over and emitting negative signals (bad news), which together ultimately prompted investors to sell their holdings (Corbet et al., 2020; Machmuddah et al., 2020). This situation is due to this COVID-19 epidemic by altering stock market dynamics, causing stock exchanges around the world to decline, leading to growing incompetence in the market (Dia et al., 2020; Lalwani \& Meshram, 2020; Liu et al., 2020; Ngwakwe, 2020).

Phan and Narayan (2020) studied the COVID-19 pandemic and reported a perpetual rapid increase, as shown in increasing infection rates and mortality. Affected countries began to respond by shutting down economic activity and the people movement, banning travel, and performing stimulus packages to protect the economy and prevent job losses. The results of their study attested how stock prices could respond in real-time to pandemic situations, such as harsh news spreads and excessive market reactions. With the dissemination of more information, the public becomes more informed and will gradually understand the situation.

Akhtaruzzaman et al (2020) investigated the means of financial dissemination through financial and non-financial companies between China and G7 countries during the COVID-19 period. Empirical data recorded that such companies listed in the $\mathrm{G} 7$ countries experienced a significant increase in the conditional relationship between stock returns. Nonetheless, the magnitude of the correlation increase was much higher for finance companies during the COVID-19 response. The optimum hedging ratio developed significantly and, in many cases, was higher throughout the COVID-19 period.

The COVID-19 pandemic, compared to the last global financial crisis, has caused prominent fear among investors. In turn, vagueness also makes gold and bonds safer investment options. To mitigate the adverse effects of the pandemic, some immediate responses need to be taken, such as organising public funds to support the health system, financial support for individuals and small and medium enterprises, financial support for companies to avoid job losses, and liquidity guarantees in the domestic market. Also, Islamic finance can afford an alternative monetary system in sustaining communities and entrepreneurs moved by the COVID-19 epidemic.

Haroon and Rizvi (2020) analysed the relationship between sentiment generated by coronavirus-related news and equity market volatility. The ongoing coronavirus outbreak has generated unprecedented news coverage and outpouring of opinions in this era of rapid information dissemination. The uncertainty that arises in the financial markets prompts price fluctuations. The study unearthed an unusual panic due to outlet news related to developed volatility in the equity market. Results from individual economic sectors symbolised that news with supported panic contributed more to the reported volatility.

Zaremba et al (2020) examined government interventions intended at limiting the influence of COVID-19 on volatile stock markets. They established that non-pharmaceutical interventions significantly increased equity market volatility. The effect, nevertheless, did not depend on the role of the coronavirus outbreak itself. There are two types of steps that can 
be taken and are usually used chronologically, i.e. holding information campaigns in advance and cancellation of public events. Both of these measures can compose a vital contribution to overcoming growth volatility. Baig et al (2020) studied the effects of the COVID-19 pandemic on the microstructure of the United States equity market. The study described the dynamics of liquidity and volatility through an index that captured the various dimensions of the epidemic.

Therefore, they confirmed that the increase in confirmed cases of infections and deaths due to coronavirus was associated with a significant increase in market liquidity and volatility. Likewise, declining sentiment and restrictions and the imposition of movement control order contributed to liquidity and market stability deterioration. Zhang et al (2020) maintained that the rapid spread of the COVID-19 virus holds a dramatic impact on financial markets worldwide.

Coronaviruses have posed an unprecedented level of risk that affected investors to face substantial losses in a short period. This research successfully mapped the general pattern of country-specific risk and systemic risk at the global level of financial markets. In addition, policy interventions render some repercussions, such as the US decision to impose a zero per cent interest rate, unlimited easing, and the extent to which these policies could create uncertainty to global financial markets.

\section{Conclusion}

The volatility of each index is influenced by the level of volatility of the previous day. This decline is inseparable due to the adverse impact on stock performance due to the COVID-19 outbreak. Ergo, the investment basis is quintessential to studying the behaviour of the company's response to the effects of the COVID-19 pandemic for the current and subsequent years. Furthermore, one should grasp the development of the COVID-19 pandemic and the economy to avoid making the wrong judgment in every investment. Portfolios need to be continuously structured and results-tailored to investment manoeuvrings and situations in existing investment instruments. The government should also stimulate stock market stability by increasing the number of aid recipients in priority sectors and administering more intensive socialisation on the dangers and prevention of COVID-19. Germane measures need to be exercised by investors, including reducing investment losses by directing fundamental and technical analysis, stock portfolio management, identifying business sectors that are resistant to disease outbreaks, and exploring the most advanced knowledge on company states.

\section{Reference}

Aali-Bujari, A., Venegas-Martínez, F., \& Pérez-Lechuga, G. (2017). Impact of the Stock Market Capitalization and The Banking Spread in Growth and Development in Latin American: A Panel Data Estimation with System GMM. Contaduriay Administracion 62(5): 1427-1441. https://doi.org/10.1016/j.cya.2017.09.005

Abdulkarim, F., Akinlaso, M., Hamid, B. A., \& Ali, H. (2020). The Nexus between Oil Price and Islamic Stock Markets in Africa: A Wavelet and Multivariate-GARCH Approach. Borsa Istanbul Review 20(2): 108-120. https://doi.org/10.1016/j.bir.2019.11.001

Akhtaruzzaman, M., Boubaker, S., \& Sensoy, A. (2020). Financial Contagion During COVID-19 Crisis. Finance Research Letters, 1-35. 
https://doi.org/10.1016/j.frl.2020.101604

Al-Awadhi, A. M., Alsaifi, K., Al-Awadhi, A., \& Alhammadi, S. (2020). Death and Contagious Infectious Diseases: Impact of the COVID-19 Virus on Stock Market Returns. Journal of Behavioral and Experimental Finance 27: 1-5. https://doi.org/10.1016/j.jbef.2020.100326

Alali, M. S. 2020. Risk Velocity and Financial Markets Performance: Measuring the Early Effect of COVID-19 Pandemic on Major Stock Markets Performance. International Journal of Economics and Financial Research 6(64): 76-81. https://doi.org/10.32861/ijefr.64.76.81

Ashraf, B. N. (2020). Stock Markets' Reaction to COVID-19: Cases or Fatalities? Research in International Business and Finance 54: 1-18. https://doi.org/10.1016/j.ribaf.2020.101249

Baig, A. S., Butt, H. A., Haroon, O., \& Rizvi, S. A. R. (2020). Deaths, Panic, Lockdowns and US Equity Markets: The Case of COVID-19 Pandemic. Finance Research Letters 19. https://doi.org/10.1016/j.frl.2020.101701

Bayraktar, N. (2014). Measuring Relative Development Level of Stock Markets: Capacity and Effort of Countries. Borsa Istanbul Review 14(2): 74-95. https://doi.org/10.1016/j.bir.2014.02.001

Bose, U., MacDonald, R., \& Tsoukas, S. (2019). Policy Initiatives and Firms' Access to External Finance: Evidence from a Panel of Emerging Asian Economies. Journal of Corporate Finance 59: 162-184. https://doi.org/10.1016/j.jcorpfin.2016.09.008

Corbet, S., Hou, Y., Hu, Y., \& Oxley, L. (2020). The Influence of the COVID-19 Pandemic on Asset-price Discovery: Testing the Case of Chinese Informational Asymmetry. International Review of Financial Analysis 72: 1-32. https://doi.org/10.1016/j.irfa.2020.101560

Coşkun, Y., Seven, Ü., Ertuğrul, M., \& Ulussever, T. (2017). Capital Market and Economic Growth Nexus: Evidence from Turkey. Central Bank Review 17(1):19-29. https://doi.org/10.1016/j.cbrev.2017.02.003

Hamid, A. B. A. (2020). The effects of Coronavirus (COVID-19) in the tourism industy in China. Asian Journal of Multidisciplinary Studies, 3(1), 1-7. International Air Transport Association (IATA) (2020). COVID-19 puts over half of 2020 passenger revenues at risk. Retrieved from https://www.iata.org/en/pressroom/pr/2020- 04-14-01/

Haroon, O., \& Rizvi, S. A. R. (2020). COVID-19: Media Coverage and Financial Markets Behavior-A Sectoral Inquiry.Journal of Behavioral and Experimental Finance 27: 15. https://doi.org/10.1016/j.jbef.2020.100343

Hassan, M. K., Rabbani, M. R., \& Abdulla, Y. (2021). Socioeconomic Impact of COVID-19 in MENA region and the Role of Islamic Finance. International Journal of Islamic Economics and Finance (IJIEF) 4(1): 51-78. https://doi.org/10.18196/ijief.v4i1.10466

Khan, H. H., Naz, I., Qureshi, F., \& Ghafoor, A. (2017). Heuristics and Stock Buying Decision: Evidence from Malaysian and Pakistani Stock Markets. Borsa Istanbul Review 17(2): 97-110. https://doi.org/10.1016/j.bir.2016.12.002

Khan, K., Zhao, H., Zhang, H., Yang, H., Shah, M. H., \& Jahanger, A. (2020). The Impact of COVID-19 Pandemic on Stock Markets: An Empirical Analysis of World Major Stock Indices. Journal of Asian Finance, Economics and Business 7(7): 463-474. https://doi.org/10.13106/jafeb.2020.vol7.no7.463 
Lalwani, V., \& Meshram, V. V. 2020. Stock Market Efficiency in the Time of Covid-19: Evidence from Industry Stock Returns. International Journal of Accounting \& Finance Review 5(2):40-44. https://doi.org/10.46281/ijafr.v5i2.744

Lawal, A. I., Somoye, R. O., Babajide, A. A., \& Nwanji, T. I. (2018). The Effect of Fiscal and Monetary Policies Interaction on Stock Market Performance: Evidence from Nigeria. Future Business Journal 4(1): 16-33.

Liu, H., Manzoor, A., Wang, C., Zhang, L., \& Manzoor, Z. (2020). The COVID-19 Outbreak and Affected Countries Stock Markets Response. International Journal of Environmental Research and Public Health 17(8): 1-19. https://doi.org/10.3390/ijerph17082800

Lyócsa, Š., Baumöhl, E., Výrost, T., \& Molnár, P. (2020). Fear of the Corona Virus and the Stock Markets. Finance Research Letters 36: 1-7. https://doi.org/10.1016/j.frl.2020.101735

Lys, T., Naughton, J., \& Wang, C. (2015). Signaling Through Corporate Accountability Reporting. Journal of Accounting and Economics 60(1): 56-72. https://doi.org/10.1016/j.jacceco.2015.03.001

Machmuddah, Z., Utomo, S. D., Suhartono, E., Ali, S., \& Ghulam, W. A. (2020). Stock Market Reaction to COVID-19: Evidence in Customer Goods Sector with the Implication for Open Innovation. Journal of Open Innovation: Technology, Market, and Complexity 6(4): 1-13. https://doi.org/10.3390/joitmc6040099

Ngwakwe, C. (2020). Effect of Covid-19 Pandemic on Global Stock Market Values: A Differential Analysis. Acta Universitatis Danubius Economica 16(2): 255-269.

Wang, Y., Zhang, D., Wang, X., \& Fu, Q. (2020). How Does COVID-19 Affect China' s Insurance Market? Emerging Markets Finance and Trade 56(10): 2350-2362. https://doi.org/10.1080/1540496X.2020.1791074

World Health Organization. (2020). Coronavirus disease 2019 situation report-67. World Health Organ.. https://www.who.int/emergencies/diseases/novelcoronavirus-2019/situationreports.

Worldometer (2020). Coronavirus. Retrieved from https://www.worldometers.info/coronavirus/

Zaremba, A., Kizys, R., Aharon, D. Y., \& Demir, E. (2020). Infected Markets: Novel Coronavirus, Government Interventions, and Stock Return Volatility around the Globe. Finance Research Letters 35: 1-14. https://doi.org/10.1016/j.frl.2020.101597

Zaremba, A., Long, H., \& Karathanasopoulos, A. (2019). Short-Term Momentum (Almost) Everywhere. Journal of International Financial Markets, Institutions \& Money 63: 1-53. https://doi.org/10.1016/j.intfin.2019.101140

Zhang, D., Hu, M., \& Ji, Q. (2020). Financial markets under the global pandemic of COVID19. Finance Research Letters 36(March), 101528. https://doi.org/10.1016/j.frl.2020.101528 